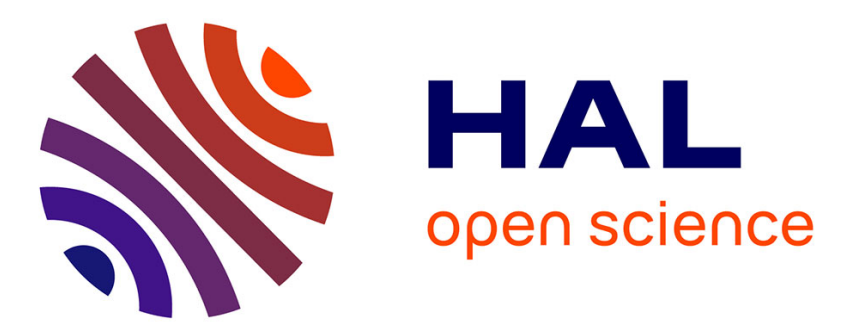

\title{
Spatial variability of nutrient stocks in the humus and soils of a forest massif (Fougeres, France)
}

\author{
A. Legout, Christian Walter, C. Nys
}

\section{To cite this version:}

A. Legout, Christian Walter, C. Nys. Spatial variability of nutrient stocks in the humus and soils of a forest massif (Fougeres, France). Annals of Forest Science, 2008, 66 (3), non paginé. 10.1051/forest:2007080 . hal-00729911

HAL Id: hal-00729911

https://institut-agro-rennes-angers.hal.science/hal-00729911

Submitted on 31 May 2020

HAL is a multi-disciplinary open access archive for the deposit and dissemination of scientific research documents, whether they are published or not. The documents may come from teaching and research institutions in France or abroad, or from public or private research centers.
L'archive ouverte pluridisciplinaire HAL, est destinée au dépôt et à la diffusion de documents scientifiques de niveau recherche, publiés ou non, émanant des établissements d'enseignement et de recherche français ou étrangers, des laboratoires publics ou privés.

$$
\text { Copyright }
$$




\title{
Spatial variability of nutrient stocks in the humus and soils of a forest massif (Fougères, France)
}

\author{
Arnaud LEGOUT ${ }^{1}$, Christian WALTER ${ }^{2}$, Claude NYS ${ }^{1 *}$ \\ ${ }^{1}$ Institut National de Recherche Agronomique, UR Biogéochimie des Écosystèmes Forestiers, 54280 Champenoux, France \\ ${ }^{2}$ UMR INRA/Agrocampus Sol-Agronomie-Spatialisation, 65 rue de Saint-Brieuc, CS 84215, 35042 Rennes Cedex, France
}

(Received 6 October 2006; accepted 21 September 2007)

\begin{abstract}
In this study, the spatial distribution of nutrient stocks ( $\mathrm{K}, \mathrm{Ca}, \mathrm{Mg}$ and $\mathrm{P}$ ) was examined in humus and soils at the forest massif scale (Fougères forest, France). A random stratified sampling plan including 100 sampling points was used and three potential variation factors of nutrient stocks were tested: age of stand, type of stand (broad-leaved or coniferous trees) and type of soil. Sampling classes were then compared and the variation factors were examined. Results demonstrated that nutrient stocks in the humus were not influenced by the cited factors and only the type of soil influenced nutrient stocks in soils. In fact, stocks of exchangeable elements in soils were much higher in Colluviosols-Fluviosols which show redoximorphic characteristics, and available phosphorus stocks were lower than in Alocrisols-Neoluvisols. Moreover, a low variability of nutrient stocks was observed in Alocrisols-Neoluvisols as opposed to Colluviosols-Fluviosols, which may suggest the existence of other variation factors not taken into account in this study (hydromorphic gradient, type and age of stand in hydromorphic zones).
\end{abstract}

nutrient stock / Fagus sylvatica / humus / soil / spatial variability

Résumé - Variabilité spatiale des réserves de nutriments dans les humus et les sols d'un massif forestier (Fougères, France). Dans ce travail, la distribution spatiale des réserves de nutriments $(\mathrm{K}, \mathrm{Ca}$ et $\mathrm{Mg}$ et $\mathrm{P})$ dans les sols et les humus a été étudiée à l'échelle d'un massif forestier (Forêt de Fougères, France). Un plan d'échantillonnage aléatoire stratifié regroupant 100 sites a été utilisé et trois facteurs potentiels de variation des stocks de nutriments ont été testés : âge et type de peuplements (feuillus et résineux) et type de sol. Les classes d'échantillonnage ont ensuite été comparées et les facteurs de variation des stocks examinés. Les résultats montrent que les réserves de nutriments dans les humus ne sont pas influencées par les facteurs cités précédemment alors que seul le type de sol influence les réserves dans les sols. Les stocks de nutriments échangeables dans les sols sont en effet significativement plus élevés et les stocks de phosphore assimilable plus faibles dans les Colluviosols-Fluviosols à caractère hydromorphe en comparaison des Alocrisols-Néoluvisols. De plus, la variabilité des stocks pour les Alocrisols-Néoluvisols est faible en comparaison des ColluviosolsFluviosols, ce qui suggère l'existence d'autres facteurs de variation non pris en compte lors de l'étude (gradient d'hydromorphie, type et âge des peuplements dans les zones hydromorphes).

stocks de nutriments / Fagus sylvatica / humus / sol / variabilité spatiale

\section{INTRODUCTION}

In forest ecosystems, the mineral fertility of soils is an important parameter controlling the productivity and sustainability of the system [31]. The soil operates as a reactor which accumulates or releases nutrients related to ecosystem parameters [37]. As opposed to agriculture, nutrient recycling is specific to forest ecosystems and usually maintains soil nutrient stocks at constant levels. However, forest ecosystems are fragile and Bonneau et Ranger [9] reported a decline in the soil mineral fertility of several French forests. The stocks of nutrients and the factors which influence these stocks have already been investigated at local scales as part of a study of the components of biogeochemical cycles in forest ecosystems. However, further developments at larger scales are required to provide accurate spatial information about forest soil nutrient supplies and about factors influencing these stocks.
In France, nutrient stocks of $\mathrm{K}, \mathrm{Ca}, \mathrm{Mg}$ (exchangeable) and $\mathrm{P}$ (available) in forest soils vary within a broad range of values, from $100 \mathrm{~kg} \cdot \mathrm{ha}^{-1}$ to $10000 \mathrm{~kg} \cdot \mathrm{ha}^{-1}$ [34,36]. A lot of factors influence the nutrient stocks and to obtain accurate information about them, their spatial variability must be considered. For that, the vertical and lateral heterogeneity may be subdivided [3].

Vertical distribution of stocks in forested landscapes is generally characterised by nutrient accumulation in organic horizons in the topsoil. The sequence of mechanisms that shapes the vertical distribution of soil nutrients can be grouped into three major processes: biogeochemical cycling, biological cycling and plant cycling [22]. Lateral variability of stocks is more difficult to characterise, due to the greater number of factors which influence nutrient stocks at different spatial scales. In fact, some forest soil properties may vary over only a few metres or less, while other properties may vary at the kilometre scale [20]. Regarding short range variability, several studies point out that individual trees can affect the chemical

*Corresponding author: nys@ nancy.inra.fr 
properties of soil (such as $\mathrm{pH}$, organic carbon, $\mathrm{Ca}, \mathrm{Mg}, \mathrm{P}$ and $\mathrm{N}$ concentrations) in their proximity, at ranges of $25 \mathrm{~m}$ or less [8, 11, 19, 20,38]. Regarding wide range variability (ranges superior to $50 \mathrm{~m}$ ), studies have proved that soil chemical properties vary with soil type, present pedogenesis, nature of parental material [45], soil position in the landscape [43], tree species $[4,5]$, stand age $[18,28,29,47]$ and type of forest management [32]. The major difficulty is that wide range variability may be concealed by short range variability.

The number and sometimes the complexity of the variation factors previously cited probably explain the small number of spatial distribution studies on soil chemical properties under forest $[10,20,28,39,48]$. Further developments in this domain are also required and could improve the future management of forests (for example, well thought-out enrichment in damaged forest ecosystem or the choice of appropriate forest species) in a context of ecosystem sustainability [31]. Several approaches, summarised by Ryan et al. [39], make the study or the cartography of nutrient stocks possible: the use of environmental correlation models [39], geostatistical methods [20] or stratification methods $[10,28,48]$ which offer advantages. In fact, stratification, following detailed identification of variation factors, allows one to investigate the distribution of element stocks at different spatial scales at an acceptable cost, such as the carbon in Lecointe et al. [28].

The aim of this study was to examine the spatial variability of nutrient stocks (exchangeable $\mathrm{K}, \mathrm{Ca}, \mathrm{Mg}$ and available $\mathrm{P}$ ) in the humus and soils, at a forest massif scale (Fougères, 1660 ha). The objectives were (i) to determine which factors among those studied (age of stand, type of stand and type of soil), influence the nutrient stocks in soils and humus, and (ii) to verify whether a stratification method previously used to investigate carbon stocks could be used for nutrient stocks. For that, we reused a stratification method initially developed by Lecointe et al. [28] for the estimation of carbon stocks at the same site. Measurements at sampling points distributed throughout the forest massif, allowed us to estimate the nutrient stocks at specific points. These stocks were then calculated for each sampling class and classes were then compared.

\section{MATERIALS AND METHODS}

\subsection{Experimental site}

The study was carried out in the state forest of Fougères (1660 ha), located in north east Brittany, France (48 23' 4" N; $1^{\circ} 8^{\prime} 10^{\prime}$ W). Beech (Fagus sylvatica) covers $75 \%$ of the forested surface and oak (Quercus robur) 15\%. Conifers (mainly Pinus sylvestris L. and P. laricio Poir.) covered $8 \%$ of the forested area before the 1999 storm. The climate is temperate oceanic with a mean annual precipitation of $868 \mathrm{~mm}$ and a mean annual temperature of $12.9{ }^{\circ} \mathrm{C}$ [26]. The difference between the maximum elevation $(191 \mathrm{~m})$ and the minimum elevation $(115 \mathrm{~m})$ is slight, but there are numerous small valleys and the stream network is highly developed.

The bedrock is a granite (Vire type) and the weathered substrate thickness fluctuates between 3 and $5 \mathrm{~m}$ [46]. A non-carbonated Aeolian loam covers the main area of the forest. The loam is about $1.5 \mathrm{~m}$ thick in the south and east of the forest, and less in the west; it contains about $15 \%$ clay and $75 \%$ silt [28]. Toutain [44] pointed out the homogeneity of these forest soils, which are mainly classified as Alocrisols-Neoluvisols [1]. Nevertheless, the soil type changes with landscape position and Colluviosols-Fluviosols [1] were identified in the valley bottoms [28] and show redoximorphic characteristics.

For this forest, Jabiol [21] pointed out that the humus forms depend especially on the age of the stands: a mull in the young stands, which is progressively transformed into a moder in the older stands.

\subsection{Sampling strategy}

A quantification of organic carbon stocks had already been carried out on this area in 2003 [28]. The same humus and soil samples, collected in April 2003, were used as a basis for this study. The sampling strategy was a random stratified plan, based on the available cartographic information, i.e. the ONF forest stand map and also the 1/15000 soil map [44]. Three factors (their choice is justified in [28]) were considered to discriminate the variation of carbon stocks: stand age, stand type (broad-leaved or coniferous trees) and soil hydromorphy. In this way, 6 independent sampling classes were created:

- 4 classes of broad-leaved trees with different ages: 0-15 years old including regeneration plots (class 1), 15-60 years old (class 2), 60-90 years old (class 3) and $>90$ years old (class 4 ).

- 1 class of conifers of all ages (class 5), which occupied $8 \%$ of the forest before the 1999 storm; different age classes could not be distinguished due to the small areas covered by these species.

- 1 class of hydromorphic zones (class 6) which occupies 9\% of the forest.

One hundred points were therefore sampled throughout the forest; the number of points in each class was approximately relative to the surface area of the class. Thus, there were 20 points for each broadleaved trees class (class 1 to 4), 10 points for the class of coniferous stands (class 5) and 10 points for the hydromorphic zones (class 6).

For each class, the position of the points was chosen randomly on a $200 \mathrm{~m}$ interval sampling grid; points were located in the field by GPS (maximum error: $25 \mathrm{~m}$ ). Soil was sampled at each point using a drill auger and detailed descriptions were made. Descriptions revealed 92 Alocrisols-Neoluvisols and 8 Colluviosols-Fluviosols. The 8 Colluviosols-Fluviosols all belonged to sampling class 6 (hydromorphic zones), but 2 sites of this class have been identified as Alocrisols-Neoluvisols, due to the lack of precision of the $1 / 15000$ soil map [44]. The classes and the 100 sampling points are presented in Figure 1.

For each point, 5 humus samples including all the organic horizons (Ol, Of and $\mathrm{Oh}[1])$ were collected within a $0.1 \mathrm{~m}^{2}$ quadrat, at a maximum distance of $5 \mathrm{~m}$ around the central point. For the mineral soil, samples were collected at 6 different levels: $0-5 \mathrm{~cm}, 5-15 \mathrm{~cm}$, $15-30 \mathrm{~cm}, 30-45 \mathrm{~cm}, 45-60 \mathrm{~cm}$ and $60-70 \mathrm{~cm}$. For the topsoil samples $(0-5 \mathrm{~cm}, 5-15 \mathrm{~cm}), 4$ other samples were collected below the humus sampling points to obtain a composite sample.

\subsection{Laboratory analyses}

For each site, humus samples were oven-dried separately at $65{ }^{\circ} \mathrm{C}$ to a constant weight, to determine the dry matter; then, samples were mixed in order to obtain a homogeneous composite sample. Total 


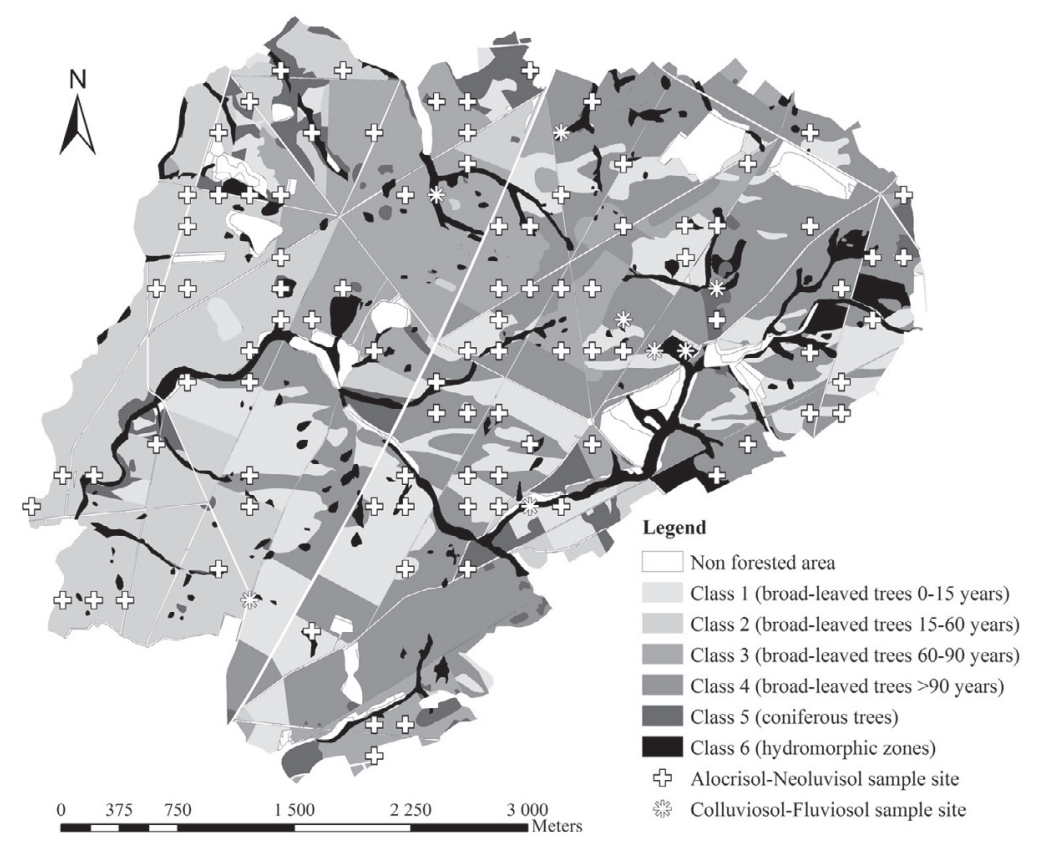

Figure 1. Map of the sampling strategy: presentation of the 6 sampling classes and the 2 soil types related to the 100 sampling points (92 Alocrisols-Neoluvisols and 8 Colluviosols-Fluviosols). There were 20 points in each broad-leaved trees class (class 1 to 4 ), 10 points for the class of coniferous trees (class 5) and 10 points for the hydromorphic zones (class 6).

$\mathrm{C}$ and $\mathrm{N}$ were determined by a carbon nitrogen elemental analyser (CHN: NCS2500, ThermoQuest) following fine grinding of the samples [28]. Total $\mathrm{K}, \mathrm{Ca}, \mathrm{Mg}$ and $\mathrm{P}$ were determined by ICP-AES (Inductively Coupled Plasma-Atomic Emission Spectrometry) following wet mineralisation.

Soil samples were air dried for several days and sieved to remove the fraction superior to $2 \mathrm{~mm}$. Particle size fractions were determined for levels 5-15 cm, 30-45 cm and 60-70 cm (NF X 31-107). Carbon and nitrogen were determined by a carbon nitrogen elemental analyser [28]. Exchangeable cations were determined by ICP-AES following extraction with cobaltihexamin chloride $(0,05 \mathrm{M}): \mathrm{K}^{+}, \mathrm{Ca}^{2+}$, $\mathrm{Mg}^{2+}$ and $\mathrm{Na}^{+}$according to the norm NF X 31-130 and $\mathrm{Mn}^{2+}, \mathrm{Fe}^{2+}$, $\mathrm{Al}^{3+}$ and $\mathrm{H}^{+}$[15]. The $\mathrm{CEC}_{\text {effective }}$ (ECEC) and base saturation were calculated for each sample. Samples were also analysed for available $\mathrm{P}$ [17] and $\mathrm{pH}_{w}$ according to the norm NF ISO 10390.

The calculation of nutrient stocks was thus based on concentrations of total $\mathrm{K}, \mathrm{Ca}, \mathrm{Mg}$ and $\mathrm{P}$ for the humus and concentrations of exchangeable $\mathrm{K}, \mathrm{Ca}, \mathrm{Mg}$ and available $\mathrm{P}$ for the soils.

\subsection{Stock calculation}

The local humus stocks were calculated for total $\mathrm{C}, \mathrm{N}, \mathrm{K}, \mathrm{Ca}, \mathrm{Mg}$ and $\mathrm{P}$, using the formula:

$$
\operatorname{Sh}(x)=\frac{M S \times X}{100}
$$

where: $\operatorname{Sh}(x)\left(\mathrm{kg} \cdot \mathrm{ha}^{-1}\right)$ is the humus stock of a nutrient $x, M S\left(\mathrm{~g} \cdot \mathrm{m}^{-2}\right)$ the dry matter content (mean of the 5 samples) and $X\left(\mathrm{~g}^{\mathrm{kg}} \mathrm{gg}^{-1}\right)$ the nutrient concentration.
The local soil stocks $(0-70 \mathrm{~cm})$ were calculated for $\mathrm{C}, \mathrm{N}$, exchangeable $\mathrm{K}, \mathrm{Ca}, \mathrm{Mg}$ and available $\mathrm{P}$. The calculation was based on the following formula:

$$
S s(x)_{0-70}=\sum_{i=1}^{6} X_{i} \times D_{i} \times T_{i} \times 100
$$

where: $S s(x)_{0-70}\left(\mathrm{~kg} \cdot \mathrm{ha}^{-1}\right)$ is the soil stock of a nutrient $x, X_{i}\left(\mathrm{~g}_{\mathrm{kg}} \mathrm{kg}^{-1}\right)$ the nutrient concentration of the layer $i, D_{i}\left(\mathrm{~g} . \mathrm{cm}^{-3}\right)$ the soil massdensity of the layer $i$ and $T_{i}(\mathrm{~cm})$ the thickness of the layer $i$.

Soil mass-density was predicted using a statistical model [6]:

$$
D_{i}=\exp \left(0,7053-0,352 \times \sqrt{C_{i}}\right)-0,044 \times E-0,0449 \times \ln (S)
$$

where: $D_{i}\left(\mathrm{~g} . \mathrm{cm}^{-3}\right)$ was the soil mass-density of the layer $i, C_{i}(\%)$ the carbon concentration of the layer $i, S$ the percentage of sand and $E$ the percentage of the $>2 \mathrm{~mm}$ particle size fraction. For our study, the percentage of sand was fixed at $20 \%$ (mean of the 100 sites, all depth mixed together), and the percentage of the $>2 \mathrm{~mm}$ fraction at $0 \%$ (no particles $>2 \mathrm{~mm}$ were determined on the soil samples). An external validation was performed in situ: 18 points were chosen out of the 100: 14 Alocrisols-Neoluvisols and 4 redoximorphic soils (Colluviosols-Fluviosols). Three volumetric samples were collected (cylinder diameter $=8 \mathrm{~cm}$, height $=$ thickness of the level considered) for each level at each point. Samples were oven-dried at $105{ }^{\circ} \mathrm{C}$ to a constant weight to determine the soil mass-density; the soil massdensity was the average of the 3 samples for this level.

\subsection{Statistical and spatial analysis of nutrient stocks}

As the mapping plan was based on a randomly stratified strategy, spatial analysis of nutrient stocks depended on statistical comparisons 
Table I. Means of $\mathrm{pH}_{\mathrm{w}}$, effective cation exchange capacity (ECEC; cmol+. $\left.\mathrm{kg}^{-1}\right)$, base saturation (BS; \%) and percentage of aluminium $\left(\mathrm{Al}^{3+}\right.$; $\%)$ on the soil exchange complex, related to soil types and soil depth $(\mathrm{cm})$, for the 100 sample points of the Fougères Forest. Confidence intervals are given in brackets.

\begin{tabular}{|c|c|c|c|c|c|c|c|c|}
\hline \multirow[b]{2}{*}{ Level } & \multicolumn{4}{|c|}{$\begin{array}{c}\text { Alocrisols-Neoluvisols } \\
(n=92)\end{array}$} & \multicolumn{4}{|c|}{$\begin{array}{l}\text { Colluviosols-Fluviosols } \\
\qquad(n=8)\end{array}$} \\
\hline & $\mathrm{pH}_{\mathrm{w}}$ & ECEC & BS & $\mathrm{Al}^{3+}$ & $\mathrm{pH}_{\mathrm{w}}$ & ECEC & BS & $\mathrm{Al}^{3+}$ \\
\hline $0-5 \mathrm{~cm}$ & $3.8_{(0.07)}$ & $8.7_{(0.7)}$ & $26_{(2.5)}$ & $56_{(3.3)}$ & $4.5_{(0.38)}$ & $10.7_{(3.2)}$ & $49_{(27.1)}$ & $40_{(22.4)}$ \\
\hline $5-15 \mathrm{~cm}$ & $4.0_{(0.05)}$ & $5.0_{(0.3)}$ & $11_{(1.1)}$ & $79_{(1.8)}$ & $4.6_{(0.26)}$ & $7.1_{(2.7)}$ & $52(23.5)$ & $43_{(23.5)}$ \\
\hline $15-30 \mathrm{~cm}$ & $4.3_{(0.05)}$ & $2.6_{(0.2)}$ & $9_{(0.9)}$ & $84_{(1.3)}$ & $4.7_{(0.41)}$ & $5.6_{(1.8)}$ & $49_{(27.3)}$ & $46_{(25.9)}$ \\
\hline $30-45 \mathrm{~cm}$ & $4.4_{(0.04)}$ & $1.8_{(0.2)}$ & $10_{(1.1)}$ & $83_{(1.7)}$ & $4.8_{(0.27)}$ & $5.1_{(1.9)}$ & $58_{(25.1)}$ & $36_{(23.7)}$ \\
\hline $45-60 \mathrm{~cm}$ & $4.4(0.06)$ & $2.2(0.3)$ & $11_{(1.5)}$ & $82(2.1)$ & $4.9_{(0.24)}$ & $4.7_{(1.4)}$ & $67_{(19.0)}$ & 28 (18.7) \\
\hline $60-70 \mathrm{~cm}$ & $4.5_{(0.07)}$ & $3.1_{(0.4)}$ & $13_{(2.5)}$ & $82_{(2.7)}$ & $4.9_{(0.31)}$ & $4.4_{(1.3)}$ & $72_{(19.0)}$ & $25_{(18.6)}$ \\
\hline
\end{tabular}

between sampling classes. For each nutrient, means of each sampling class for the humus and 0-70 cm soil stocks were compared using a multiple comparison Tukey test. If the differences were not significant, classes could be regrouped for further analysis or representations. The influence of factors on nutrient stocks in humus and soils were thus examined: the "stand age" for broad-leaved trees, the "stand type" (broad-leaved or coniferous trees) and the "hydromorphic character" of soils which will be associated in this paper with the factor "soil type"; except for two sample sites, these hydromorphic zones (class 6) have always been identified as ColluviosolsFluviosols, not found in the other sampling classes.

In addition, Pearson correlation tests were performed for each element between humus total nutrient stocks and exchangeable $\left(\mathrm{K}_{2} \mathrm{O}\right.$, $\mathrm{CaO}, \mathrm{MgO})$ or available $\left(\mathrm{P}_{2} \mathrm{O}_{5}\right)$ nutrient stocks contained in the upper levels of the soil $(0-5 \mathrm{~cm}$ and $0-15 \mathrm{~cm})$.

Statistical analyses were performed using Unistat 5.0 software and all significant statistical tests were at the $5 \%$ threshold.

A quantification of errors related to point stock estimation was performed using Monte-Carlo simulation methods [13]. We carried out simulations to try to quantify the accuracy of the evaluation of a point-based soil nutrient stock. The principle is based on a simulation relationship between parameters entered into the model respecting the distribution laws for each parameter. For the soils and the humus, the errors on stocks due to sampling and analyses remained relatively small. The main source of uncertainty lay in the model estimating bulk mass-density (Tab. II). Using 1000 simulations we evaluated the effect of these measurement errors on nutrient stocks in the soil after grouping classes 1 to 5 (broad-leaved and coniferous trees), as no significant differences between these classes were observed.

\section{RESULTS}

\subsection{Properties of Fougères forest soils}

The $\mathrm{pHs}_{(\mathrm{w})}$ of Alocrisols-Neoluvisols were very low (Tab. I), with an increase from the surface downwards, from 3.8 to 4.5 . These soils were desaturated (BS $<20 \%$ ) for almost all levels. The percentage of exchangeable aluminium on the soil exchange complex was $>50 \%$ in the topsoil and $>80 \%$ in the lower levels. Protons occupied about $15 \%$ of the soil exchange capacity in the topsoil and 5\% at depth. The cation exchange capacity decreased from the surface to depth, from $8.7 \mathrm{cmol}+. \mathrm{kg}^{-1}$ to $1.8 \mathrm{cmol}+. \mathrm{kg}^{-1}$ at $30-45 \mathrm{~cm}$, with an increase in the deepest level to $3.1 \mathrm{cmol}+. \mathrm{kg}^{-1}$.

The $\mathrm{pHs}_{(\mathrm{w})}$ were higher for Colluviosols-Fluviosols than for Alocrisols-Neoluvisols; nevertheless, an increase from the surface to depth (4.5 to 4.9) was also observed. These soils were meso-saturated $(50 \%<\mathrm{BS}<80 \%)$; the percentage of base saturation increased with depth, related to the decrease of the percentage of exchangeable aluminium on the soil exchangeable complex (40\% in the topsoil to $25 \%$ in the deeper levels). The cation exchange capacity was higher than for the Alocrisols-Neoluvisols, and decreased from $10.7 \mathrm{cmol}+. \mathrm{kg}^{-1}$ in the surface to $4.4 \mathrm{cmol}+. \mathrm{kg}^{-1}$ in the deepest level.

According to the confidence interval, the soil properties of Alocrisols-Neoluvisols were always less variable than Colluviosols-Fluviosols.

\subsection{Validation of soil mass-density estimation}

Results of the external validation are presented in Table II. The Belkacem et al. [6] model slightly underestimated the mass-density observed for the 18 sites (mean error = $0.06 \mathrm{~g} . \mathrm{cm}^{-3}$ ). Predictions by the model were better when hydromorphic soils were removed from the calculation, especially for the intermediate levels; in fact, the RMSE decreased from $0.23 \mathrm{~g} . \mathrm{cm}^{-3}$ to $0.12 . \mathrm{cm}^{-3}$ for the $30-45 \mathrm{~cm}$ level.

\subsection{Correlation between soil and humus stocks}

Pearson correlations between total nutrient stocks in humus and exchangeable $(\mathrm{K}, \mathrm{Ca}, \mathrm{Mg})$ or available $(\mathrm{P})$ stocks in the 0-5 cm and 0-15 cm soil levels (Tab. III) were not significant, except for $\mathrm{K}_{2} \mathrm{O}$, and this correlation was very weak $(0.23)$.

\subsection{Lateral distribution of nutrient stocks}

\subsubsection{Nutrient stocks in humus}

Statistics of nutrient stocks for the humus and for each class are presented in Table IV. No significant difference existed for 
Table II. Statistics $\left(\mathrm{g} . \mathrm{cm}^{-3}\right)$ of external validation for the soil density prediction model (Belkacem et al., 1998) tested for the Fougères Forest and related to soil types. Statistics are presented firstly for all depths and then for the 5-15, 30-45 and 60-70 levels (cm). The mean error (Mean error) is the mean of the differences between the observed soil density and the estimated soil density. The root mean square error (RMSE) is presented too.

\begin{tabular}{lccc}
\hline Level & Parameters & All soil types $(n=18)$ & Non hydromorphic soils $(n=14)$ \\
\hline \multirow{2}{*}{$0-70 \mathrm{~cm}$} & Mean error & 0.06 & 0.03 \\
& RMSE & 0.19 & 0.15 \\
\multirow{2}{*}{$5-15 \mathrm{~cm}$} & Observed soil density & 0.96 & 0.97 \\
& Mean error & 0.05 & 0.02 \\
& RMSE & 0.18 & 0.19 \\
$30-45 \mathrm{~cm}$ & Observed soil density & 1.29 & 1.32 \\
& Mean error & 0.06 & -0.01 \\
$60-70 \mathrm{~cm}$ & RMSE & 0.23 & 0.12 \\
& Observed soil density & 1.53 & 1.57 \\
\end{tabular}

Table III. Pearson correlations for each nutrient, between total nutrient stocks in the humus and exchangeable or available nutrient stocks in the $0-5 \mathrm{~cm}$ and $0-15 \mathrm{~cm}$ soil layers. Pearson correlations are calculated on the 100 sample sites. Significant correlations at the 0.05 level are indicated by the symbol (*).

\begin{tabular}{lcc}
\hline Element & $\begin{array}{c}\text { Pearson correlation } \\
\text { between stocks in humus } \\
\text { and soil layer } 0-5 \mathrm{~cm}(n=100)\end{array}$ & $\begin{array}{c}\text { Pearson correlation } \\
\text { between stocks in humus } \\
\text { and soil layer } 0-15 \mathrm{~cm}(n=100)\end{array}$ \\
\hline $\mathrm{K}_{2} \mathrm{O}$ & $-0.23 *$ & $-0.23 *$ \\
$\mathrm{CaO}$ & -0.01 & -0.08 \\
$\mathrm{MgO}$ & 0.03 & -0.05 \\
$\mathrm{P}_{2} \mathrm{O}_{5}$ & -0.09 & -0.12 \\
\hline
\end{tabular}

Table IV. Statistics of nutrient stocks for the 100 points, related to the sampling classes. Means $\left(\mathrm{kg} \cdot \mathrm{ha}^{-1}\right)$ are presented for humus and $0-70 \mathrm{~cm}$ soil stocks. Confidence intervals are given in parenthesis. On a table line, significant differences between classes are indicated by different letters (Tukey test at 95\% level). For detailed information about classes, see Figure 1.

\begin{tabular}{|c|c|c|c|c|c|c|c|c|c|c|c|c|c|}
\hline \multirow{3}{*}{$\mathrm{K}_{2} \mathrm{O}\left(\mathrm{kg} \cdot \mathrm{ha}^{-1}\right)$} & \multirow{3}{*}{$\begin{array}{c}\text { Humus stocks } \\
0-70 \mathrm{~cm} \text { soil stocks }\end{array}$} & \multicolumn{2}{|c|}{$\begin{array}{l}\text { Class 1: } \\
(n=20)\end{array}$} & \multicolumn{2}{|c|}{$\begin{array}{l}\text { Class 2: } \\
(n=20)\end{array}$} & \multicolumn{2}{|c|}{$\begin{array}{l}\text { Class 3: } \\
(n=20)\end{array}$} & \multicolumn{2}{|c|}{$\begin{array}{l}\text { Class 4: } \\
(n=20)\end{array}$} & \multicolumn{2}{|c|}{$\begin{array}{l}\text { Class 5: } \\
(n=10)\end{array}$} & \multicolumn{2}{|c|}{$\begin{array}{l}\text { Class 6: } \\
(n=10)\end{array}$} \\
\hline & & $129^{a}$ & (52) & $132^{\mathrm{a}}$ & (29) & $124^{\mathrm{a}}$ & (31) & $149^{\mathrm{a}}$ & (27) & $86^{\mathrm{b}}$ & (29) & $119^{\mathrm{a}}$ & (71) \\
\hline & & $290^{\mathrm{a}}$ & (28) & $292^{\mathrm{a}}$ & (40) & $270^{\mathrm{a}}$ & (23) & $273^{\mathrm{a}}$ & (28) & $273^{\mathrm{a}}$ & (29) & $342^{\mathrm{a}}$ & (91) \\
\hline \multirow{2}{*}{$\mathrm{CaO}\left(\mathrm{kg} \cdot \mathrm{ha}^{-1}\right)$} & Humus stocks & $125^{\mathrm{a}}$ & (39) & $140^{\mathrm{a}}$ & (20) & $155^{\mathrm{a}}$ & (21) & $165^{\mathrm{a}}$ & (35) & $154^{\mathrm{a}}$ & (46) & $146^{\mathrm{a}}$ & (61) \\
\hline & 0-70 cm soil stocks & $222^{\mathrm{a}}$ & (24) & $195^{\mathrm{a}}$ & (23) & $185^{\mathrm{a}}$ & (17) & $194^{\mathrm{a}}$ & (39) & $191^{\mathrm{a}}$ & (40) & $3690^{\mathrm{b}}$ & (2265) \\
\hline \multirow{2}{*}{$\mathrm{MgO}\left(\mathrm{kg} \cdot \mathrm{ha}^{-1}\right)$} & Humus stocks & $67^{\mathrm{a}}$ & (21) & $78^{\mathrm{a}}$ & (20) & $72^{\mathrm{a}}$ & (13) & $84^{\mathrm{a}}$ & (15) & $65^{\mathrm{a}}$ & (20) & $74^{\mathrm{a}}$ & (34) \\
\hline & $0-70 \mathrm{~cm}$ soil stocks & $180^{\mathrm{a}}$ & (29) & $162^{\mathrm{a}}$ & (23) & $198^{\mathrm{a}}$ & (50) & $178^{\mathrm{a}}$ & (26) & $178^{\mathrm{a}}$ & (27) & $1432^{b}$ & $(550)$ \\
\hline \multirow{2}{*}{$\mathrm{P}_{2} \mathrm{O}_{5}\left(\mathrm{~kg} \cdot \mathrm{ha}^{-1}\right)$} & Humus stocks & $71^{\mathrm{a}}$ & (27) & $65^{\mathrm{a}}$ & (9) & $101^{\mathrm{a}}$ & (19) & $113^{\mathrm{a}}$ & (20) & $95^{\mathrm{a}}$ & (27) & $69^{\mathrm{a}}$ & (41) \\
\hline & $0-70 \mathrm{~cm}$ soil stocks & $1428^{\mathrm{a}}$ & (192) & $1378^{\mathrm{a}}$ & (168) & $1404^{\mathrm{a}}$ & (200) & $1394^{\mathrm{a}}$ & (160) & $1427^{\mathrm{a}}$ & (218) & $913^{\mathrm{b}}$ & (511) \\
\hline
\end{tabular}

the humus stocks between classes whatever the nutrients were, except for $\mathrm{K}_{2} \mathrm{O}$ stocks which were lower in coniferous stands $\left(86 \mathrm{~kg} \cdot \mathrm{ha}^{-1}\right)$ than in other classes.

Figure 2 shows the dry matter stocks and nutrient concentrations in the humus, related to the defined classes. The dry matter stocks were about 50 t.ha $^{-1}$ in the oldest broadleaved tree classes (classes 3 and 4 ) and in the coniferous class (class 5), while they were $<40 \mathrm{t}^{-\mathrm{ha}^{-1}}$ in the other classes, al- though no significant differences were observed due to high within-class variability. Except for P, total nutrient concentrations were generally lower in the coniferous stands (class 5) than in other classes, although few significant differences were observed. Conversely, except for $\mathrm{P}$, total nutrient concentrations were always higher in the hydromorphic zones (class 6), and significant differences were observed between class 6 and classes 3, 5 and 4, except for $\mathrm{K}$ in class 4 . 

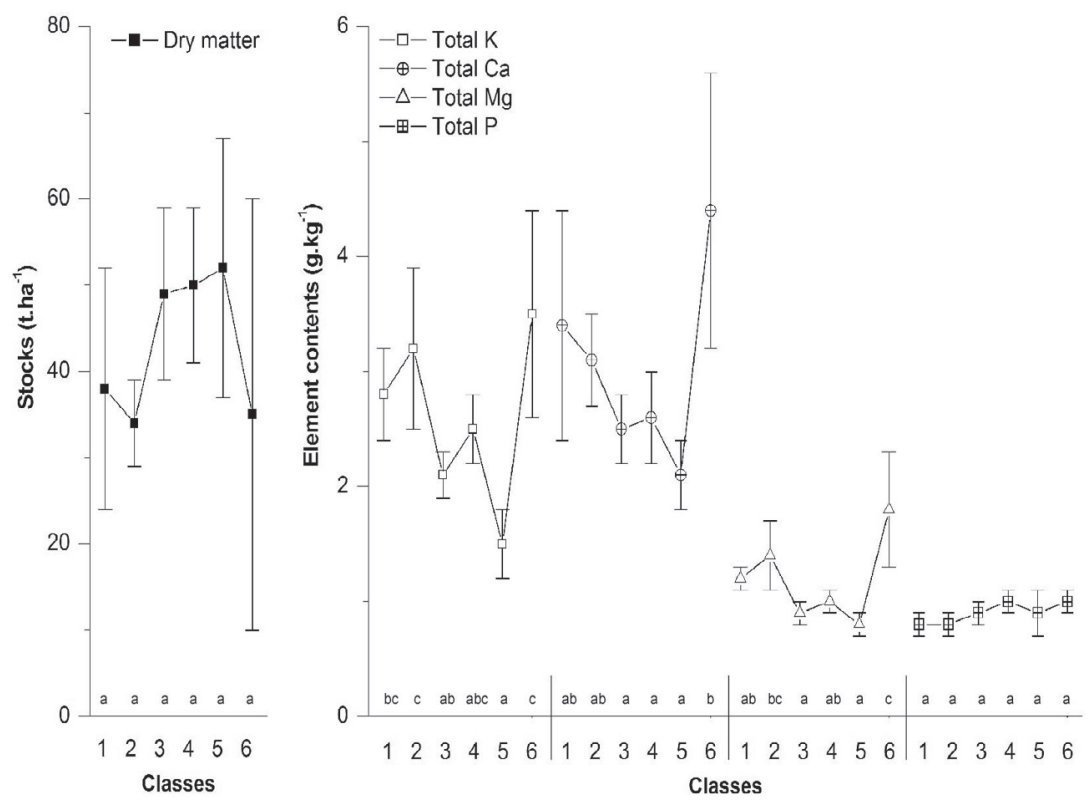

Figure 2. Means of stocks of dry material $\left(\mathrm{t}_{\mathrm{ha}} \mathrm{h}^{-1}\right)$ and means of total element contents $\left(\mathrm{g} \cdot \mathrm{kg}^{-1}\right)$ in humus related to sampling classes. Means which differ significantly between classes are indicated by different letters (Tukey test at $95 \%$ level). Confidence intervals are represented by vertical bars. For detailed information about classes, see Figure 1.

\subsubsection{Nutrient stocks in soil}

The soil stocks were significantly higher in the hydromorphic zones (class 6) for exchangeable $\mathrm{CaO}$ and $\mathrm{MgO}$, respectively $3690 \mathrm{~kg} \cdot \mathrm{ha}^{-1}$ and $1432 \mathrm{~kg} \cdot \mathrm{ha}^{-1}$ compared to other classes (Tab. IV). Conversely, available $\mathrm{P}_{2} \mathrm{O}_{5}$ stocks $\left(913 \mathrm{~kg} \cdot \mathrm{ha}^{-1}\right)$ were significantly lower in the hydromorphic zones than in other classes. As for classes 1 to 5, low variability was noticed within classes and there was no significant difference between classes.

\subsection{Vertical distribution of nutrient stocks}

The distribution of soil nutrient stocks related to depth and sampling class is presented in Figure 3. Differences between total soil stocks in classes 1 to 5 were not significant (Tab. IV) and classes 1 to 5 were therefore amalgamated for this representation.

Exchangeable $\mathrm{K}_{2} \mathrm{O}$ stocks in classes 1 to 5 were equitably distributed with depth, with about $50 \mathrm{~kg} \cdot \mathrm{ha}^{-1}$ in each level sampled, while the profile of exchangeable $\mathrm{K}_{2} \mathrm{O}$ stocks in class 6 was convex, with a maximum in the $15-30 \mathrm{~cm}$ level $\left(75 \mathrm{~kg}^{-h a^{-1}}\right)$ and minimums in the $0-5 \mathrm{~cm}$ and $60-70 \mathrm{~cm} \mathrm{lev-}$ els (about $40 \mathrm{~kg} \cdot \mathrm{ha}^{-1}$ ).

Exchangeable $\mathrm{CaO}$ stocks in classes 1 to 5 decreased from the surface to depth from 67 to $24 \mathrm{~kg} \cdot \mathrm{ha}^{-1}$, whereas the profile of exchangeable $\mathrm{CaO}$ stocks of class 6 was convex like that of $\mathrm{K}_{2} \mathrm{O}$ stocks, with however a deeper observed maximum equal to $812 \mathrm{~kg} \cdot \mathrm{ha}^{-1}$ in the $30-45 \mathrm{~cm}$ level. The lowest stock was in the $0-5 \mathrm{~cm}$ level $\left(282 \mathrm{~kg} \cdot \mathrm{ha}^{-1}\right)$.

Exchangeable $\mathrm{MgO}$ stocks in classes 1 to 5 decreased from the surface down to the $30-45 \mathrm{~cm}$ level (from 44 to $19 \mathrm{~kg} \cdot \mathrm{ha}^{-1}$ ) and then increased in the deepest levels up to $38 \mathrm{~kg} \cdot \mathrm{ha}^{-1}$. The profile of exchangeable $\mathrm{MgO}$ stocks in class 6 was convex too, with a maximum of $401 \mathrm{~kg} \cdot \mathrm{ha}^{-1}$ observed in the $45-60 \mathrm{~cm}$ level and a minimum of $84 \mathrm{~kg} \cdot \mathrm{ha}^{-1}$ in the $0-5 \mathrm{~cm}$ level.

Profiles of available $\mathrm{P}_{2} \mathrm{O}_{5}$ stocks related to depth were convex whatever the class; however, the convex distribution was more pronounced in classes 1 to 5 than in class 6 , with maximums equal to 385 and $214 \mathrm{~kg}$.ha ${ }^{-1}$ and minimums of 100 and $60 \mathrm{~kg} \cdot \mathrm{ha}^{-1}$ respectively.

According to the confidence intervals, the variability was low in classes 1 to 5 whatever the level and the nutrient, whereas variability in class 6 was higher than other classes whatever the level, generally with maximum variability in the intermediate levels.

\subsection{Accuracy of the estimates}

The Monte Carlo approach provided a quantification of the accuracy of the evaluation of a point-based soil nutrient stock. The uncertainty in classes 1 to 5 was revealed by the standard deviation of soil stocks which was $22.8 \mathrm{~kg}^{-h^{-1}}$ for exchangeable $\mathrm{K}_{2} \mathrm{O}, 24.9 \mathrm{~kg} \cdot \mathrm{ha}^{-1}$ for exchangeable $\mathrm{CaO}$, $18.2 \mathrm{~kg} . \mathrm{ha}^{-1}$ for exchangeable $\mathrm{MgO}$ and $77.5 \mathrm{~kg}^{-h^{-1}}$ for available $\mathrm{P}_{2} \mathrm{O}_{5}$. The uncertainty was higher in class 6 , respectively $50.8 \mathrm{~kg} \cdot \mathrm{ha}^{-1}$ for exchangeable $\mathrm{K}_{2} \mathrm{O}, 570.8 \mathrm{~kg} \cdot \mathrm{ha}^{-1}$ for exchangeable $\mathrm{CaO}, 182.1 \mathrm{~kg} \cdot \mathrm{ha}^{-1}$ for exchangeable $\mathrm{MgO}$ and $137.6 \mathrm{~kg} \cdot \mathrm{ha}^{-1}$ for available $\mathrm{P}_{2} \mathrm{O}_{5}$.

\section{DISCUSSION}

We recall for the discussion, that sampling classes 1 to 5 corresponded to Alocrisols-Neoluvisols while class 6 

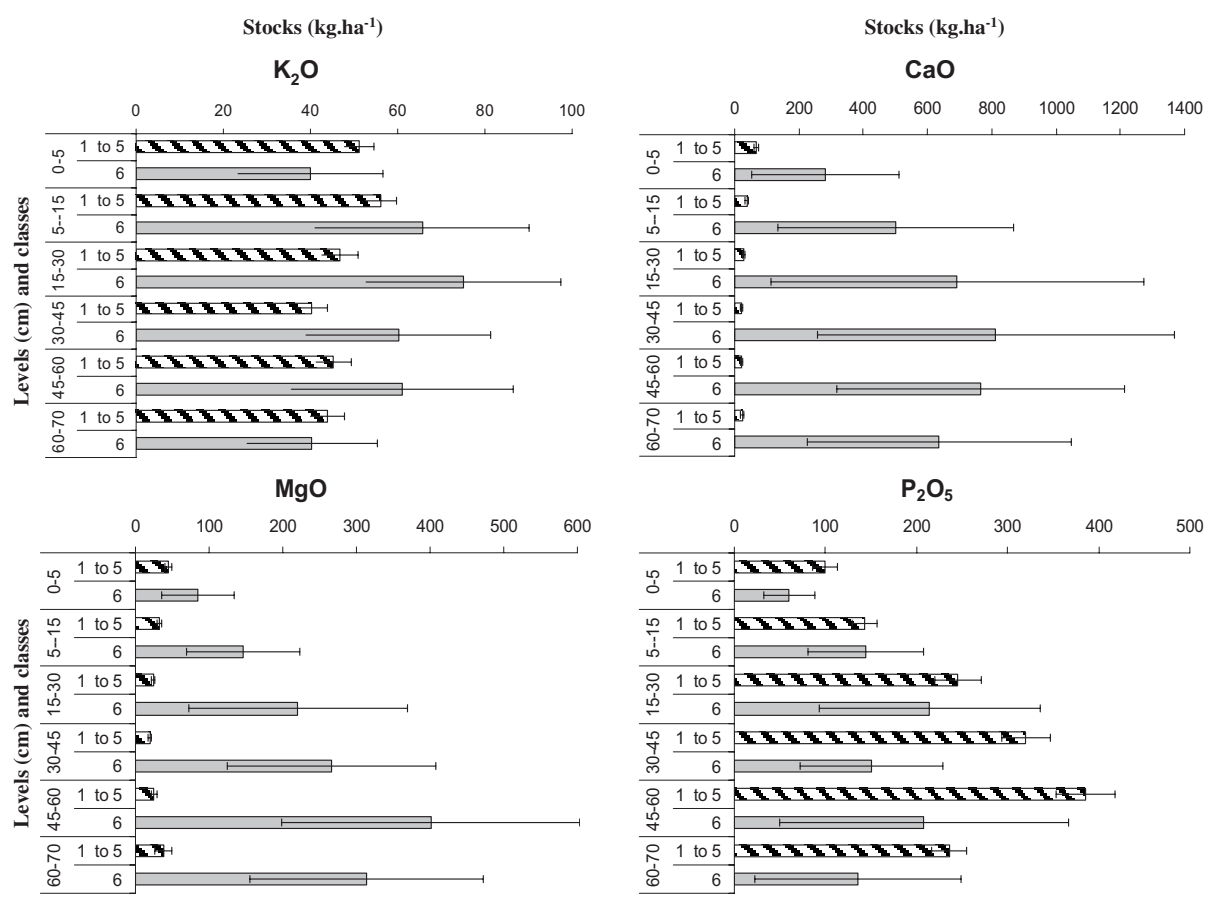

Figure 3. Means of the nutrient stocks $\left(\mathrm{kg}_{\mathrm{h}} \mathrm{ha}^{-1}\right)$ contained in soils, related to levels $(\mathrm{cm})$ and sampling classes. Confidence intervals are represented by horizontal bars. Sampling classes 1 to $5(n=90)$ corresponded to Alocrisols-Néoluvisols while class $6(n=10)$ corresponded mainly to Colluviosols-Fluviosols ( 8 sites for a total of 10 sites in this class).

corresponded mainly to Colluviosols-Fluviosols ( 8 sites for a total of 10 sites in this class).

\subsection{Nutrient stocks in humus and soils}

Total nutrient stocks in the humus represented a large part of the exchangeable nutrient stocks contained in the $0-70 \mathrm{~cm}$ level (Tab. IV): about $70 \%$ for $\mathrm{CaO}$ and about $40 \%$ for $\mathrm{K}_{2} \mathrm{O}$ and $\mathrm{MgO}$. In an ecosystem characterised by poor fertility, as in the Fougères Massif, the recycling of the most limiting elements for plant growth by biological cycling is of primary importance [35]. Therefore nutrient stocks in the humus represented a large part of the exchangeable nutrient stocks of soils and were particularly essential, and all the more so because these nutrients were the mostly easily available. Conversely, total phosphorus stocks in the humus represented less than $10 \%$ of the stock of available phosphorus contained in the $0-70 \mathrm{~cm}$ level (Tab. IV), as it was not a limiting element in the Fougères Massif ecosystem.

The relationships between stocks in humus and stocks in the upper soil horizon were not significant, except for $\mathrm{K}_{2} \mathrm{O}$ (Tab. III), which demonstrated a complex relationship between these two contiguous components of the ecosystem. Few studies deal with the relationship between stocks in humus and stocks in the upper soil horizon ; nevertheless, we may suppose that a distinction between the humus layers $(\mathrm{Ol}$, Of and $\mathrm{Oh}$ ) and division of the surface soil into thinner sampling lev- els would have shown better relationships between humus and soil nutrient concentrations or stocks, as in Chodak et al. [14].

Consequently, as the relation between humus and soil surface stocks was insignificant or very weak for $\mathrm{K}_{2} \mathrm{O}$ (Tab. III), we chose to discuss these two components of nutrient stocks separately.

\subsection{Factor influence on humus stocks}

\subsubsection{Effects of stand characteristics}

Total nutrient stocks in the humus related to the age of the stands may be tested only for broad-leaved trees (mainly beech), as all ages were mixed for classes 5 (coniferous) and 6 (hydromorphic zones). Concerning classes 1 to 4 , the age of stand had no significant effect on total humus nutrient stocks, whatever the element (Tab. IV), at the forest massif scale. However, the two components used for stock calculation in humus were affected by this factor (Fig. 2). On the one hand, the concentrations of total elements in humus decreased with the ageing of the stands, probably due to a superior concentration of nutrients in leaves returned to soil in the younger stands $[16,26]$. On the other hand, the dry matter stock under beech in the Fougères massif increased with the age of the stand (Fig. 2), related to the transformation of mull to a moder humus type, and with a thickening of the humus layers (Of and $\mathrm{Oh}$ ). This phenomenon has already been observed by other authors [27]. So, total nutrient concentrations varied 
inversely with stocks of dry matter during the ageing of the broad-leaved stands, and the calculation of total nutrient stock in humus resulted in a fairly constant value, independent from the age class of the stands.

The comparison of total nutrient stocks in class 5 with classes 1 to 4 suggested that in the context of the Fougères massif, the type of stand (broad-leaved or coniferous trees) did not influence the total nutrient stocks in the humus (Tab. IV). The chemical composition of foliage returned to the soil influenced the nutrient status of humus; coniferous trees usually have lower foliage concentrations of $\mathrm{K}, \mathrm{Ca}$ and $\mathrm{Mg}$ than broadleaved trees [5], such as beech [24]. Thus, litterfall of broadleaved trees can be richer in nutrients than conifers [5]. Except for $\mathrm{P}$, this tendency was respected for total element concentrations in the humus of the Fougères massif; in fact contents were always lower under coniferous than under broad-leaved tree stands, although no significant differences were observed except for K (Fig. 2). For the Fougères massif, the higher stock of dry matter under coniferous compared to broad-leaved trees resulted in total nutrient stocks in humus being homogeneous between broad-leaved trees and coniferous stands, except for $\mathrm{K}_{2} \mathrm{O}$.

\subsubsection{Effects of the soil hydromorphy}

The hydromorphic characteristics of Fougères soils did not significantly influence total nutrient stocks in humus; the generally higher concentrations of elements in class 6 compared to other classes (Fig. 2) were compensated for in terms of stocks by the lower quantity of dry matter in that class. However, the variable humus forms on these hydromorphic soils may present very diverse properties or functioning; so, the amalgamation of all these waterlogged humus forms in the same class increased the intra-class variability and the low number of each form meant that our observations could not be explained.

\subsection{Factor influence on soil stocks}

\subsubsection{Effects of stand characteristics}

At the scale of the Fougères Massif, exchangeable or available nutrient stocks in the soil were homogeneous in classes 1 to 4 and 5, namely within broad leaved tree stands and coniferous stands (Tab. IV). There was no significant effect of the type of stand on nutrient stocks. Present understanding of the effects of tree species on soil fertility remains very incomplete and there is no complete agreement on a species ranking with respect to their potential effects on soil fertility [2, 25, 33, 42]. Time is often a limiting factor in these studies, as the impact of species on soil characteristics at a time scale of a few decades is often significant only in the first $10 \mathrm{~cm}$ of the topsoil [5]. Binkley [7] reported that conifers often occur on poor soils, but no generalisation about impoverishment by conifers is apparent from ordinary experiments, which was confirmed by the Fougères forest massif.
On the other hand, in the context of the Fougères massif, the age of broad-leaved trees stands did not have any effect on the nutrient stocks in soils whatever the element. It was for that reason that Ovington [33] criticised short term studies and emphasised that changes with time were not as great as papers indicated, due to faulty experimental layout. Anderson [2] concluded that over a whole rotation, the effect on soil may not be as significant as suggested by data analyses of samples taken in early to mid-rotation.

\subsubsection{Effects of soil type and hydromorphy}

In the Fougères massif, soil type was the principal factor studied which shaped the vertical distribution of exchangeable or available nutrient stocks (the differences between classes 1 to 5 and class 6 are shown in Fig. 3). A lower stock variability by level was observed in the Alocrisols-Neoluvisols compared with the Colluviosols-Fluviosols (Fig. 3) and confirmed the high spatial variability of soil properties in these locations [12, $23,30,41]$.

Although the vertical distribution of exchangeable element stocks $\left(\mathrm{K}_{2} \mathrm{O}, \mathrm{CaO}, \mathrm{MgO}\right)$ depended on the element considered, the greater part of soil nutrient stocks for the AlocrisolsNeoluvisols (classes 1 to 5) was located in the upper horizons of the soil, except for exchangeable $\mathrm{MgO}$. The vertical distribution of nutrient stocks in this type of soil followed the decrease of ECEC with depth (Tab. I), which may be explained by the exponential decrease of carbon contents in the Alocrisols-Neoluvisols of the Fougères Massif [28]. On the other hand, according to Jobbagy et Jackson [22], the vertical distribution of soil nutrients will be shallower as nutrients become increasingly scarce. In fact, biological cycling by plants exerted a dominant control on the vertical distribution of the most limiting elements for plants [22]. This control may occur in the Fougères ecosystem (characterised by poor fertility) and explain the accumulation of exchangeable nutrients in the upper soil horizons of the Alocrisols-Neoluvisols.

Colluviosols-Fluviosols (class 6) had larger stocks than Alocrisols-Neoluvisols and a different exchangeable element stock $\left(\mathrm{K}_{2} \mathrm{O}, \mathrm{CaO}, \mathrm{MgO}\right)$ distribution, especially when depth increased (Fig. 3). A high ECEC value (Tab. I), whatever the depth, combined with the increase of soil mass-density with depth could result in superior stocks in the deepest levels. In this type of soil, a large part of the ECEC may be attributed to organic matter, the soils being an accumulation of several organic and mineral levels due to successive deposition. In any case, Lecointe et al. [28] reported that organic carbon stocks in the soil were twice as high in Colluviosols-Fluviosols as in Alocrisols-Neoluvisols. The differences between nutrient stocks in these two types of soil were very high for $\mathrm{CaO}$ and $\mathrm{MgO}$, stocks being much higher in Colluviosols-Fluviosols. It is supposed that these elements were present in large quantities in that location, probably released by alluvial and colluvial materials or supplied by water-table fluctuation.

The vertical allocation of available phosphorus stocks was relatively similar between the two soil types, but with lower stocks in the Colluviosols-Fluviosols (Fig. 3). Lyons et al. [30] 
noted that soil properties, such as organic matter, soil moisture, $\mathrm{pH}$, amorphous $\mathrm{Fe}$ and $\mathrm{Al}$ are known to influence phosphorus retention. Stevenson [40] specified that organic matter may coat $\mathrm{Fe}$ and $\mathrm{Al}$ oxides, thus blocking potential sorption sites and decreasing phosphorus adsorption. As organic carbon stocks in the soils of the Fougères Massif were twice as high for Colluviosols-Fluviosols as for AlocrisolsNeoluvisols [28], we suppose that this type of phenomenon occurred and decreased the phosphorus adsorption potential.

Consequently, the vertical allocation of exchangeable or available nutrient stocks in soils led to large differences between soil nutrient stocks in classes 1 to 5 (AlocrisolsNeoluvisols) compared to class 6 (Colluviosols-Fluviosols) (Tab. IV). Thus, the type of soils in the Fougères Massif had a large influence on the lateral distribution of nutrient soil stocks. On the other hand, the wide variability previously observed, by level, in class 6 logically affected to the total soil nutrient stocks, which then showed the largest intra-class variability (Tab. IV). Conversely, the intra-class variability in the Alocrisols-Neoluvisols (classes 1 to 5) was generally low.

\subsection{Accuracy and limits of the study}

For total nutrient stocks in humus, the statistical analyses proved that there were no significant differences between sampling classes. The highest variability of total nutrient stocks in humus was the intra-class variability, especially for classes 1 (youngest broad-leaved trees), 5 (coniferous class) and 6 (hydromorphic zones) (Tab. IV), which could be partly explained by the construction of these classes. In fact, class 5 regrouped all coniferous species, of all ages combined. Class 6 regrouped all of the hydromorphic zones, amalgamating all the waterlogged humus forms. Class 1 regrouped all the youngest broad-leaved trees and the regeneration stands (with seedling trees still in place) were integrated into this class. Finally, all these groupings contributed to the increase of intra-class variability and proved that the choice of these 6 sampling classes was not necessarily accurate and the number of sampling classes needed to be increased in classes 1, 5 and 6 . Nevertheless, this sampling design allowed the differences in nutrient contents and dry matter quantity between classes to be observed (Fig. 2).

For exchangeable or available nutrient stocks in soils, we could have obtained the same results using fewer classes ( 2 instead of 6), as for the total nutrient stocks in humus. Nevertheless, nutrient stock variability in soils was low for classes 1 to 5 , which proved that no other major factor variation occurred. However, uncertainty about the estimation of nutrient stocks in soils was higher in the hydromorphic zones than in other classes. In fact, we evaluated the effect of these measurement errors on nutrient stocks in the soil, to be $\sim 8 \%$ for the sampling class groups 1 to 5 and $\sim 14 \%$ for class 6 . Thus, the number of sampling classes needed to be increased in hydromorphic zones depending on the degree of hydromorphy and on the type and age of stands. This would have provided a better understanding of the factors causing variation in soil nutrient stocks.

\section{CONCLUSION}

The method, combining point estimates and existing maps with a scale change, was initially designed to estimate the total carbon stocks of the whole forest but the use that we made of it appeared accurate. This method allowed us to analyse the spatial distribution of nutrient stocks ( $\mathrm{K}, \mathrm{Ca}, \mathrm{Mg}$ and $\mathrm{P}$ ) at the scale of a forest massif for humus and soil $(0-70 \mathrm{~cm})$ and among the studied variation factors, we identified those influencing the nutrient stocks.

For the humus, neither the type nor the age of the stand, nor the hydromorphic character of the soils, significantly influenced the total nutrient stocks. Nevertheless, a large part of the variability was not explained and other variation factors may occur.

For the soil, stand characteristics did not influence exchangeable or available nutrient stocks, the only significant variation factor being the soil type. In fact, stocks of exchangeable elements were much higher in ColluviosolsFluviosols, and available phosphorus stocks were lower than in Alocrisols-Neoluvisols. On the other hand, AlocrisolsNeoluvisols presented a low nutrient stock variability, which proved that no major variation factor occurred. Conversely, nutrient stock variability found in Colluviosols-Fluviosols (which show redoximorphic characteristics), combined with a higher uncertainty of stock estimation, may suggest the existence of other variation factors not taken into account in this study.

Further developments are thus required, particularly when working on the hydromorphic gradient and the type and age of stand in hydromorphic zones. However, this method may allow nutrient stocks to be mapped accurately at the whole forest scale and results obtained could be included in the future management of forests. Lastly, results obtained may also be used in the framework of modelling nutrient cycle in forest ecosystems.

Acknowledgements: We would like to thank all the technicians without whom this project would not have been possible; in particular O. Quidu and G. Dutin from INRA Rennes; S. Didier, L. Gelhaye and C. Hossann from INRA Nancy. This work was partly financed by the Ministry of Research Office in the context of ECCO, and partly by the Office National des Forêts in the context of one of the Environmental Research sites on "Lowland beech" part of F-ore-T. The English was corrected by Aldyth Nys.

\section{REFERENCES}

[1] AFES, Référentiel pédologique, INRA, Paris, 1995.

[2] Anderson M., The effects of forest plantations on some lowland soils. I. A second sampling of nutrient stocks, Forestry 60 (1987) 69-85.

[3] Arrouays D., Feller C., Jolivet C., Saby N., Andreux F., Bernoux M., Estimation de stocks de carbone organique des sols à différentes échelles d'espace et de temps, Étude Gest. Sols 10 (2003) 347-355.

[4] Augusto L., Bonnaud P., Ranger J., Impact of tree species on forest soil acidification, For. Ecol. Manage. 105 (1998) 67-78.

[5] Augusto L., Ranger J., Binkley D., Rothe A., Impact of several common tree species of European temperate forests on soil fertility, Ann. For. Sci. 59 (2002) 233-253. 
[6] Belkacem S., Nys C., Dupouey J.L., Évaluation des stocks de carbone dans les sols forestiers. Importance de la sylviculture et du milieu sur la variabilité, INRA/DPE N ${ }^{\circ} 6-95 / 329 / \mathrm{P} 00006$, Agriges, 68 p., 1998.

[7] Binkley D., The influence of tree species on forest soils: processes and patterns, Special Publication - Agronomy Society of New Zealand, 1995, pp. 1-33.

[8] Boettcher S.E., Kalisz P.J., Single-tree influence on soil properties in the mountains of eastern Kentucky, Ecology 71 (1990) 13651372.

[9] Bonneau M., Ranger J., Évolution de la fertilité chimique des sols forestiers. Recommandations pour une gestion durable, La forêt privée 247 (1999) 51-64.

[10] Brack C.L., Richards G.P., Carbon accounting model for forests in Australia, Environ. Pollut. 116 (2002) 187-194.

[11] Bringmark E., Spatial variation in soil $\mathrm{pH}$ of beech forests in relation to buffering properties and soil depths, OIKOS 54 (1989) 165 177.

[12] Bruland G.L., Richardson C.J., Hydrologic gradients and topsoil additions affect soil properties of Virginia created wetlands, Soil Sci. Soc. Am. J. 68 (2004) 2069-2077.

[13] Burrough P., McDonnell R., Principles of Geographical Information Systems, Oxford University Press, Oxford, 1998.

[14] Chodak M., Ludwig B., Beese F., An equation to describe vertical gradients of element concentrations in soils under beech and spruce stands, J. Plant Nutr. Soil Sci. 165 (2002) 602-608.

[15] Ciesielski H., Sterckeman T., Determination of cation exchange capacity and exchangeable cations in soils by means of cobalt hexamine trichloride. Effects of experimental conditions, Agronomie 17 (1997) 1-7.

[16] Cole D.W., Rapp M., 6. Elemental cycling in forest ecosystems, Dynamic properties of forest ecosystems, Cambrige University Press, Cambrige, 1981, pp. 341-409.

[17] Duchaufour P., Bonneau M., Une nouvelle méthode de dosage du phosphore assimilable dans les sols forestiers, Bulletin de l'AFES 4 (1959) 193-198.

[18] Dupouey J.L., Pignard G., Badeau V., Thimonier A., Dhote J.F., Nepveu G., Berges L., Augusto L., Belkacem S., Nys C., Carbon stores and fluxes in French forests, C. R. Acad. Agric. Fr. 85 (1999) 293-310

[19] Fournier R.E., Morrison I.K., Hopkin A.A., Short range variability of soil chemistry in three acid soils in Ontario, Canada, Commun. Soil Sci. Plant Anal. 25 (1994) 3069-3082.

[20] Gonzalez O.J., Zak D.R., Geostatistical analysis of soil properties in a secondary tropical dry forest, St. Lucia, West Indies, Plant Soil 163 (1994) 45-54.

[21] Jabiol B., Évolution de la diversité et du fonctionnement des humus au cours d'une révolution forestière en futaie régulière de hêtres, Site-atelier de la forêt de Fougères, Nancy, 2000, p. 43.

[22] Jobbagy E.G., Jackson R.B., The distribution of soil nutrients with depth: Global patterns and the imprint of plants, Biogeochemistry 53 (2001) 51-77.

[23] Johnston C.A., Bridgham S.D., Schubauer-Berigan J.P., Nutrient dynamics in relation to geomorphology of riverine wetlands, Soil Sci. Soc. Am. J. 65 (2001) 557-577.

[24] Kavvadias V.A., Alifragis D., Tsiontsis A., Brofas G., Stamatelos G., Litterfall, litter accumulation and litter decomposition rates in four forest ecosystems in northern Greece, For. Ecol. Manage. 144 (2001) 113-127.

[25] Kimpe C.R.d., Martel Y.A., Effects of vegetation on the distribution of carbon, iron, and aluminium in the B horizons of Northern Appalachian spodosols, Soil Sci. Soc. Am. J. 40 (1976) 77-80.

[26] Lebret M., Les humus forestiers en hêtraie de plaine : analyse des facteurs de l'évolution dans une chronoséquence, Rennes 1, 2002, p. 350.

[27] Lebret M., Nys C., Forgeard F., Litter production in an Atlantic beech (Fagus sylvatica L.) time sequence, Ann. For. Sci. 58 (2001) 755-768.
[28] Lecointe S., Nys C., Walter C., Forgeard F., Huet S., Recena P., Follain S., Estimation of carbon stocks in a beech forest (Fougères Forest - W. France): extrapolation from the plots to the whole forest, Ann. For. Sci. 63 (2006) 139-148.

[29] Liu J., Peng C., Apps M., Dang Q., Banfield E., Kurz W., Historic carbon budgets of Ontario's forest ecosystems, For. Ecol. Manage. 169 (2002) 103-114.

[30] Lyons J.B., Gorres J.H., Amador J.A., Spatial and temporal variability of phosphorus retention in a riparian forest soil, J. Environ. Qual. 27 (1998) 895-903.

[31] Nambiar E.K.S., Sustained productivity of forests is a continuing challenge to soil science, Soil Sci. Soc. Am. J. 60 (1996) 16291642 .

[32] Olsson B.A., Bengtsson J., Lundkvist H., Effects of different forest harvest intensities on the pools of exchangeable cations in coniferous forest soils, For. Ecol. Manage. 84 (1996) 135-147.

[33] Ovington J.D., Organic production, turnover and mineral cycling in woodlands, Biol. Rev. 40 (1965) 295-336.

[34] Ranger J., Badeau V., Dambrine E., Dupouey J.L., Nys C., Party J.P., Turpault M.-P., Ulrich E., Évolution constatée des sols forestiers au cours des dernières décennies, Rev. For. Fr. LII (2000) 49-70.

[35] Ranger J., Colin-Belgrand M., Nutrient dynamics of chestnut tree (Castanea sativa Mill.) coppice stands, For. Ecol. Manage. 86 (1996) 259-277.

[36] Ranger J., Nys C., La qualité des sols forestiers français, Étude Gest. Sols 10 (2003) 165-285.

[37] Richter J., The soil as a reactor: modelling processes in the soil, Catena Verlag, Cremlingen, 1987.

[38] Riha S.J., James B.R., Senesac G.P., Pallant E., Spatial variability of soil $\mathrm{pH}$ and organic matter in forest plantations, Soil Sci. Soc. Am. J. 50 (1986) 1347-1352.

[39] Ryan P.J., McKenzie N.J., O'Connell D., Loughhead A.N., Leppert P.M., Jacquier D., Ashton L., Integrating forest soils information across scales: spatial prediction of soil properties under Australian forests, For. Ecol. Manage. 138 (2000) 139-157.

[40] Stevenson F.J., Humus chemistry: genesis, composition, reactions, John Wiley and Sons, New York, 1994.

[41] Stolt M.H., Genthner M.H., Daniels W.L., Groover V.A., Spatial variability in Palustrine wetlands, Soil Sci. Soc. Am. J. 65 (2001) $527-535$.

[42] Stone E.L., Effects of species on nutrient cycles and soil change, Philos. Trans. R. Soc. Lond. B 271 (1975) 149-162.

[43] Tchienkoua M., Zech W., Statistical analysis of soil variability in a humid forest landscape of Central Cameroon, Int. J. Appl. Earth Obs. Geoinf. 5 (2004) 69-79.

[44] Toutain F., Étude des sols et des eaux de la forêt de Fougères, Rennes, 1965, p. 192.

[45] Turpault M.P., Ranger J., Marques R., Ezzaïm A., Les bilans entrées-sorties, indicateurs de gestion durable des écosystèmes forestiers : cas des plantations de Douglas des monts du Beaujolais, Rev. For. Fr. 2 (1999) 184-196.

[46] Van Vliet-Lanoë B., Pellerin J., Helluin M., Morphogenèse, pédogénèse : les héritages du dernier cycle glaciaire en forêt de Fougères, Z. Geomorphol. N. F. 39 (1995) 489-510.

[47] Wang J.R., Zhong A.L., Kimmins J.P., Biomass estimation errors associated with the use of published regression equations of paper birch and trembling aspen, Northern J. Appl. For. 19 (2002) 128136.

[48] Zinke P.J., Stangenberger A.G., Elemental storage of forest soil from local to global scales, For. Ecol. Manage. 138 (2000) 159165. 